\title{
Polymorphism of Angiotensin-converting Enzyme Gene of Insertion/Deletion on Cardiovascular Endurance Performance of Athletes
}

\author{
Arimbi \\ Universitas Negeri Makasar \\ Makassar, Indonesia
}

\author{
Arifuddin Usman \\ Universitas Negeri Makasar \\ Makassar, Indonesia
}

\author{
Muriyati \\ Sekolah Tinggi Ilmu Kesehatan Panrita \\ Husada \\ Bulukumba, Indonesia
}

\begin{abstract}
The practical difference of the body metabolism plays a very substantial role in determining the kind of sport suitable for an athlete. One of the gene variations considered to control the potentials of an athlete is the gene variation of AngiotensinConverting Enzyme (ACE) symbolised as I and D. The ACE-I is responsible for the formation of the red muscles (slow twitch) and the ACE-D is in charge of forming the white muscles (fast twitch). This study aims at assessing how the roles of ACE gene exhaust the possibilities of the athlete's cardiovascular ability. Moreover, this study used the observational method with the prospective study approach to reveal a case in point of the correlation between one factor and the effect it causes. The findings indicated significant differences among the groups of II, ID, and DD variations of ACE gene genotype. The genotype II exposed an enhanced response to the cardiovascular endurance training compared to the genotype of DD and ID by the significant value. Also, there was a robust correlation of the variation of the angiotensin-converting enzyme of insertion/deletion and the cardiovascular duration performance of the athlete.
\end{abstract}

Keywords-Polymorphism; angiotensin-converting enzyme gene.

\section{INTRODUCTION}

The success in an endurance sport requires an aerobic level or a good cardiorespiratory. It represented by the breathing in the maximum oxygen (VO2 Max) and the endurance level. On the other hand, the short distance running and the strength sport tends to depend more on the anaerobic activities and the metabolism of the muscles. Both disciplines of the main sports involve various metabolisms of muscles. The spirit and the power sport primarily demand anaerobic or electric generating muscle metabolism, while the endurance sport depends on the aerobic metabolism.

The genetic polymorphism which acts as the mediator of the health potentials and the physical performance of a person are the targets of many groups of researchers who are attempting to reveal their roles with the genetic tendencies to produce the performance excellence and endurance. Some athletes have achieved 170 sequences of gene variants, 17 markers of mitochondrial DNA, and 25 additional markers of nuclear genetics in the genetic maps of a person related to the phenotype of physical performance and good physical fitness [1].
ACE (Angiotensin-Converting Enzyme) gene is one of the several genes which the sports branches call for physical endurance. Hence, ACE gene encodes an enzyme (angiotensin I converting enzyme) which is responsible for converting the active angiotensin I into the active angiotensin II. The angiotensin II functions to trigger the narrowing of the diameters of the blood vessels and to degradation the substances which enlarge the diameter of the blood vessels (kinins). The ACE is expressed widely in the skeletal muscles and functions as a main metabolic while doing sports [2].

Nowadays, the approach to the cultivation of sports has not yet existed, especially for the approach which uses the genetic information about the young athletes' selection in Indonesia. In fact, genetic information is very significant in providing inputs about how the body metabolism works. Thus, the difference in how the body metabolism works is critical in determining which sports branch suits an athlete or an athlete candidate [3]. If the genetic potentials are combined with the discipline development strategies and well directed, then no doubt in the upcoming few years, Indonesia will be able to achieve its greatness which is even better than in the last few decades.

Therefore, this study aims at analysing one of the variations of the genotypes that contributes to the performance of an athlete. The gene of ACE and its genotype variation plays a role in the performance of an athlete, especially when the researchers found the genetic information of the athlete earlier. Therefore, the target of this study is the young athlete candidates cultivated at Yanti Jaya club, one of the badminton clubs in South Sulawesi Region, which has quite some young athletes with the good cultivation management. Consequently, it is easier to observe and control the responses of the athletes having the genetic variation of the ACE gene to the conventional training process they perform.

\section{RESEARCH METHOD}

This study applied a Harvard Test. The observation was the first step in this study using the design or approach as the prospective study to illustrate the correlation between a factor and its factor's effect [4]. The location of the study was Yanti Jaya badminton Club, located in South Sulawesi, Indonesia. The samples of this study are all the badminton athletes in Yanti Jaya Badminton Club cultivated by 54 badminton athletes ageing $13-21$ years. The first activity in the examination of the genotype variations of Angiotensin Converting Enzyme genes was taking the blood samples.

This study implemented an ACE gene polymorphism genetic testing using polymerase chain reaction analysis. It can detect the presence of DNA at the end of the reaction and 

by the examination of the cardiovascular endurance using Harvard Step Test [5], [6].

\section{RESUlTS AND DisCUSSION}

\section{A. Results}

Characteristics of the research subjects included the age, body weight, and body height. The examination of the results of the genetic polymorphism of ACE gene in this study used the analysis method of the conventional Polymerase Chain Reaction (PCR) with the detection of the existence of DNA performed at the end of the reaction and observation of the existence of DNA. The result shows amplification of 'Agarose' gels after performing the electrophoresis. The results show in Table $1-4$. The above Table 1 showing that range ages of the great sample majority were 18 years and that the index of the cardiovascular fitness of the badminton athletes in Yanti Jaya club was good in average.

TABLE I. CARDIOVASCULAR ENDURANCE OF 3 GENETIC VARIATIONS OF ACE GENES BEFORE ROUTINE TRAINING

\begin{tabular}{|c|c|c|c|c|}
\hline \multirow{2}{*}{ Variable } & \multicolumn{3}{|c|}{ Genotype ACE genes } & \multirow{2}{*}{ P } \\
\cline { 2 - 4 } & II (SD) & ID (SD) & DD (SD) & (S5,57 \\
$\begin{array}{c}\text { Cardiovascular } \\
\text { endurance }\end{array}$ & $\mathbf{7 1 , 6 3}$ & $\begin{array}{c}65,77 \\
(18,31)\end{array}$ & $\begin{array}{c}64,57 \\
(12,99)\end{array}$ & 0,442 \\
\hline
\end{tabular}

Table 1 above indicated the cardiovascular endurance before undergoing the routine training for six months. Although the mean value had shown a significant difference between the three genotype variations of ACE genes of II, ID, and DD, based on the statistical test it did not demonstrate a significant difference between the genotype variations of ACE genes. As a comparison to the cardiovascular endurance of 3 genetic variations of ACE genes before regular training, Table 2 below showed the score after 6-month routine training.

TABLE II. THE CARDIOVASCULAR ENDURANCE OF THE THREE GENOTYPE VARIATIONS OF ACE GENES AFTER THE 6-MONTH ROUTINE TRAINING.

\begin{tabular}{|c|c|c|c|c|}
\hline \multirow{2}{*}{ Variable } & \multicolumn{3}{|c|}{ Genotype ACE genes } & \multirow{2}{*}{ P } \\
\cline { 2 - 4 } & II (SD) & ID (SD) & $\begin{array}{c}\text { DD } \\
\text { (SD) }\end{array}$ & \\
\hline $\begin{array}{c}\text { Cardiovascu- } \\
\text { lar endurance }\end{array}$ & $\mathbf{8 3 , 2 0}$ & 75,27 & 56,57 & 0,007 \\
\hline
\end{tabular}

Table 2 indicated the cardiovascular endurance based on the genotype ACE genes after undergoing the routine training program for six months. This study reveals the significant difference in the test of the cardiovascular endurance and the muscle power among the three genotype variations of ACE genes. The athlete group with the genotype of II had a higher mean value compared to the groups with the genotype variations of ID and DD as shown in Table 3 below.

The result of the correlation test of Spearman between the genotypes of ACE genes showed the change volume of $r=0.272$ and $\mathrm{p}=0.025$. After undergoing a routine training for six months, the three groups of athletes with the genotype variations of II, ID, and DD showed that the index of the cardiovascular fitness. It indicated an increase; however, the athlete group with the genotype II had shown an increase of
$11.57 \mathrm{ml} / \mathrm{kg} / \mathrm{minute}$ (higher) compared to the groups with the genotypes of ID and DD.

TABLE III. CHANGE OF CARDIOVASCULAR ENDURANCE AFTER UNDERGOING THE 6-MONTH ROUTINE TRAINING PROGRAM

\begin{tabular}{|c|c|c|c|c|}
\hline \multirow{2}{*}{$\begin{array}{c}\text { Genotype } \\
\text { ACE } \\
\text { genes }\end{array}$} & \multicolumn{2}{|c|}{$\begin{array}{c}\text { Mean (SD) Index KKV/Harvard } \\
\text { Test (ml/kg/minutes) }\end{array}$} & \multirow{2}{*}{ P } \\
\cline { 2 - 4 } & Before & After & Change & \\
\hline II (SD) & $71,63(17,73)$ & $83,20(18,10)$ & 11,57 & $<0,001$ \\
\hline ID (SD) & $65,77(18,310$ & $75,27(19,15)$ & 9,50 & 0,057 \\
\hline DD (SD) & $64,57(12,99)$ & $56,57(24,62)$ & $-8,00$ & 0,437 \\
\hline
\end{tabular}

Also, the athlete group with ID genotype showed a better change with the mean increase of $9.50 \mathrm{ml} / \mathrm{kg} / \mathrm{minute}$, while the DD genotype group experienced the reduction of the average value of $8 \mathrm{ml} / \mathrm{kg} / \mathrm{minute}$. Thus, it could be concluded that the difference of the capacity response after the six-month training was significant as shown in the cardiovascular capacity test.

\section{B. Discussion}

If the cardiovascular endurance interacts with Harvard test means that the athlete group with the variation of genotype II experienced the response of the capacity increase in their performance, higher than the athlete groups with the genotype variation of ID and DD. The responses towards the six-month training by the three groups of athletes with the genotype variations of II, ID, and DD on the cardiovascular endurance showed a higher increase in the athlete group. The genotype II compared to the athlete groups with the genotypes of ID and DD: the increase is $11.57 \mathrm{ml} / \mathrm{kg} /$ minute. The VO2max for the subjects with the genotype II was $54 \mathrm{ml} / \mathrm{kg} /$ minute, the subjects with the genotype ID was $52 \mathrm{ml} / \mathrm{kg} /$ minute, and the subjects with the genotype DD was $46 \mathrm{ml} / \mathrm{kg} /$ minute. It means that the subjects with the genotype DD had a cardiovascular fitness which significantly lower than the groups with the genotypes of either ID or DD [7]. Thus, there is a correlation between the polymorphism of Angiotensin I/D genes with the level of the cardiovascular fitness in young male athletes who walk as far as $1600 \mathrm{~m} \mathrm{[7]}$.

However, a study conducted on 230 Jamaican and American elite runners did not found a correlation between one of the athletes and the running capacity of the athlete [8]. The oxidative capacity increases were found to correlate the ACE of the athlete with D. That the ACE activities increased related to the genotype $\mathrm{DD}$, and that could cause the growth in the production of Angiotensin II, which was the dominant biological products of RAS and could mediate many local effects of ACE at skeleton muscles.

\section{CONCLUSION}

This study can conclude that aside from the various genotype interactions, some other elements such as the different forms of applied training, nutrition, ages. Moreover, anthropometry of an athlete can also affect the response capacity on the physical exercises, which is later revealed by the increase in the physical capability of the athlete - in this case, the observation on the maximum cardiovascular capacity of the athletes. Although not all of the other factors are observed in this study, the results of this study can be made of one of the resources that later the examination of the genes of Angiotensin Converting Enzyme (ACE). This study can be one of the prerequisites in selecting the athlete candidates of the badminton and other sports branches while controlling other genetic factors, which are not observed in this study to obtain better research results. 
[1] T. Rankinen, L. Pérusse, R. Rauramaa, M. A. Rivera, B. Wolfarth, and C. Bouchard, "The human gene map for performance and health-related fitness phenotypes.," Med. Sci. Sports Exerc., vol. 33, no. 6, pp. 855-67, Jun. 2001.

[2] A. C. Guyton, "Dominant role of the kidneys and accessory role of whole-body autoregulation in the pathogenesis of hypertension.," Am. J. Hypertens., vol. 2, no. 7, pp. 57585, Jul. 1989.

[3] J. R. Ruiz et al., "Is there an optimum endurance polygenic profile?," J. Physiol., vol. 587, no. 7, pp. 1527-1534, Apr. 2009.

[4] E. N. Keen and A. W. Sloan, "Observations on the Harvard Step Test," J. Appl. Physiol., vol. 13, no. 2, p. 241 LP-243, Sep. 1958.

[5] H. T. Lee, H. L. Roh, and Y. S. Kim, "Cardiorespiratory endurance evaluation using heart rate analysis during ski simulator exercise and the Harvard step test in elementary school students," J. Phys. Ther. Sci., vol. 28, no. 2, p. 641, 2016.

[6] D. A. Taddonio and P. V Karpovich, "The Harvard Step Test as a Measure of Endurance in Running," Res. Quarterly. Am. Assoc. Heal. Phys. Educ. Recreat., vol. 22, no. 3, pp. 381-384, Oct. 1951.

[7] J. A. Almeida et al., "The influence of ACE genotype on cardiovascular fitness of moderately active young men.," Arq. Bras. Cardiol., vol. 98, no. 4, pp. 315-20, Apr. 2012.

[8] R. A. Scott et al., "ACTN3 and ACE Genotypes in Elite Jamaican and US Sprinters," Med. Sci. Sport. Exerc., vol. 42, no. 1 , pp. 107-112, Jan. 2010. 